\title{
Bir Aile Sağlığı Merkezine Evlilik Raporu İçin Başvuran Kişilerin Değerlendirilmesi
}

\author{
Nurten ELKIN*
}

\section{Öz}

Amaç: Evlilik, yasalara uygun olarak iki karşı cins arasındaki bir anlaşma ile aile kurmayı, bir sonraki neslin yetişmesini sağlayan en önemli ve en temel insan ilişkisi olup; çocuk sahibi olmayı ve psikolojik, biyolojik, kültürel ve sosyo-ekonomik amaçları hedefleyen bir dayanışma ve anlaşmadır. Evlilik öncesi sağlık raporu alınması Türk Medeni Kanunu'nun 136. maddesine göre zorunlu tutulmuştur. Evlilik raporu düzenlenmesi Aile Hekimliği Kanunu'nda aile hekiminin görevleri içinde yer alan bir hizmettir. Bireylerin başvurdukları aile sağlığı merkezinde aile hekimi tarafından bazı test ve muayenelere tabi tutulmaktadır. Çalışmamızda; evlilik öncesi sağlık raporu almak için aile sağlı̆̆ı merkezine başvuran kişilerin ve tetkik sonuçlarının değerlendirilmesi amaçlanmıştır.

Yöntem: Çalışmamız 01.01.2011 ile 30.12.2013 tarihleri arasında İstanbul'daki bir aile sağlığı merkezine yapılmış tüm evlilik raporu başvurularını kapsamaktadır. Retrospektif bir çalışmadır. Verilerin analizinde ortalama, standart sapma ve frekans istatistik yöntemleri kullanılmıştır.

Bulgular: Başvuran 151 kişinin 69'unu kadın oluşturmaktadır. Venereal Disease Research Laboratory (VDRL), Anti Human Immuno Deficiency Virus (Anti-HIV) pozitifliğine ve akciğer grafileri değerlendirildiğinde tüberküloz enfeksiyonu bulgusuna rastlanmamıştır. Başvuranlardan 1 kişide Anti Hepatitis C Virüs (HCV), 3 kişide Anti Hepatit B yüzey antijen (HBs) pozitif iken, Hepatit B yüzey antijen (HBsAg) pozitifliği 3 kişide tespit edilmiştir.

Sonuç: Çalışmamızda evlilik öncesi yapılan tetkikler değerlendirildiğinde cinsel yolla bulaşan hastalıkların yaygınlığının oldukça düşük olduğu; genetik geçişli hastalıklarla ve aile planlaması ile ilgili gerekli danışmanlığın yapıldığı sonucuna varılmış olup; bu alanda daha kapsamlı

\footnotetext{
Özgün Araştırma Makalesi (Original Research Article)

Geliș / Received: 27.06.2018 \& Kabul / Accepted: 19.03.2019

${ }^{*}$ Dr. Öğr. Üyesi, İstanbul Gelişim Üniversitesi, Sağllk Bilimleri Yüksekokulu, Çocuk Gelişimi Bölümü, İstanbul, Türkiye, E-posta: nelkin@gelisim.edu.tr, ORCID ID https://orcid.org/oooo0002-9470-2702
} 
çalışmaların yapılmasının evlilik raporlarının bir prosedür olarak görülmesinden çok bu hastalıkların önlenmesi ve sağlıklı nesillerin oluşması konusunda önemli olacağı düşünülmektedir.

Anahtar Sözcükler: Aile sağlığı merkezi, evlilik raporu, evlilik öncesi muayeneler, danışmanlık.

\title{
Assessment of the Applicants for a Marriage Report to a Family Health Center
}

\begin{abstract}
Aim: Marriage is the most important human relationship by the build-up with the agreement of two opposite sexes in accordance with the law; that allows being the family and provides the growth of the next generation. It is solidarity and agreement that aims to have children and aims at psychological, biological, cultural and socio-economic goals. Before the marriage obtaining a health report has been compulsory according to Article 136 of the Turkish Civil Code. The arrangement of the marriage report is a service included in the duties of the family physician in the Law on Family Medicine. The people are subjected to some tests and examinations at the family health center by the family physician. In our study; the aim is to evaluate the test results of people who applied to the family health center.
\end{abstract}

Method: Our study covers all marriage report applications made to a Family Health Center in Istanbul between 01.01.2011 and 30.12.2013. It is a retrospective study. Mean, standard deviation and frequency statistical methods were used for data analysis.

Findings: 69 of the 151 participants is women. According to the results of the Venereal Disease Research Laboratory (VDRL), Anti-Human Immunodeficiency Virus (Anti-HIV) positivity and chest radiographs, there is no evidence of tuberculosis infection. Anti-hepatitis $\mathrm{C}$ virus (HCV) is positive in one person and Anti-Hepatitis B surface antigen (HBs) is positive in 3 subjects. Hepatitis B surface antigen (HBsAg) positivity is determined in 3 subjects.

Conclusion: In our study, the prevalence of sexually transmitted diseases is quite low. It has been concluded that necessary counseling is provided for genetic diseases and family planning. It is thought that more comprehensive studies should be done in this field and marriage reports should be considered as an important tool in preventing these diseases and forming healthy generations, not as a procedure.

Keywords: Family health center, marriage report, pre-marriage examinations, counseling. 


\section{Giriş}

Türkiye'de evlenmek isteyen kişiler, bağlı oldukları aile hekimlerine başvurarak evlilik raporu almak zorundadırlar. Başvurdukları aile sağlı̆ı merkezinde aile hekimi tarafından muayeneleri ve bazı testleri yapılmaktadır. Bu testler cinsel veya kalıtsal yolla bulaşan hastalıkları belirlemeye yöneliktir. $\mathrm{Bu}$ raporun düzenlenmesinde; hastanın bilgilerinin üçüncü kişilerle paylaşılmamasına yönelik gizlilik ilkesine özellikle dikkat edilmektedir. Evlilik raporu işlemleri Türk Medeni Kanunu'na, Umumi Hıfzıssıhha Kanunu'na ve Türk Ceza Kanunu'na göre yapılmaktadır ${ }^{1,2}$. Sağlık Bakanlığı Temel Sağlık Hizmetleri’ne göre; evlilik öncesi sağlık kurumuna yapılacak başvurular sırasında yapılacak muayene ve tetkiklerle birlikte önemi ve sıklığı gün geçtikçe hızlı artış gösteren bulaşıcı hastalıklar araştırılmakta, genetik geçişi olan hastalıklara yönelik bilgilendirme ve danışmanlık hizmeti verilerek eş adayları riskler, hastalıklar ve korunma yolları konusunda bilinçlendirilmelidirler. Kişinin önce fizik muayenesi yapılmalı daha sonra Umumi Hıfzıssıhha Kanunu'nda (UHK) belirtilen bulaşıcı hastalıklar (frengi, cüzzam, belsoğukluğu, yumuşak şankr, tüberküloz) ve akıl hastalıkları araştırılmalı; ayrıca son yıllarda artış gösteren AIDS, Hepatit C, Hepatit B hastalıkları ile genetik geçiş gösteren hastalıklarda sorgulanmalı ve araştırılmalıdır. Düzenlenecek rapor öncesinde; aile planlaması ile ilgili bilgilendirme ve tıbbi danışmanlıkta verilmelidir. Cüzzam, frengi gibi bazı hastalıklar Umumi Hıfzıssıhha Kanunu'nda da (UHK) belirtildiği gibi evlenmeye engel teşkil etmekte fakat bu hastalıkların tedavileri yapıldığı halde kişilerde kalıcı sekel bırakabilecekleri rapor düzenlenirken göz önünde bulundurulmalıdır. Akıl hastası olduğu bilinen veya şüphe edinilen kişilerin psikiyatri konsültasyonları yapılarak evlenmelerine engel durumlarının olup olmadıklarını belirten sağlık kurulu raporu almaları gerekir3. Evlilik öncesi rapor düzenlenmesinde istenen tetkiklerde bazı bölgesel farklılıklar olmasına karşın genel olarak; kan grubu, HIV, HBsAg, HCV, VDRL, akciğer röntgeni ve hemogram istenmektedir ${ }^{3,4}$.

Evlenecek kişilerden kan grubu tetkiklerinin istenmesinin nedeni eş adayları olmalarının dışında ilerideki gebelik durumlarında anne ile çocuk arasında $\mathrm{Rh}$ uygunsuzluğunun gelişip gelişmeyeceğini belirlemektir. Rh uygunsuzluğu gebelik durumunda çocuğun ve annenin sağlı̆̆ını etkileyecek bir duruma yol açacağı için; gebelik öncesi tetkiklerin yapılması ve önlem alınması gerekir. 
Hepatit B ve Hepatit C testleri ise; taşıyıcılık veya hastalığın tespiti için yapılır4. HIV; korunmasız cinsel ilişki, kan yolu ve anneden bebeğe (perinatal) geçiş gösterdiği için evlilik öncesi testler arasında yer almaktadır. Sfiliz (VDRL) testi ile frengi hastalığı taranır. Frengi, cinsel yolla bulaşan ve tedavi edilebilir bir bulaşıcı hastalıktır, bu nedenle evlilik öncesinde eş adaylarının hastalık konusunda bilgilendirilerek taşıyıcılığın tespiti ve varsa tedavisinin düzenlenmesi çok önemlidir5. Evlilik öncesinde anamnez, fizik muayene ve tetkikler ile birlikte gerekli danışmanlığın verilmesi bu hastalıkların (HIV, HBV, HCV, Sfiliz) bulaşmalarının engellenmesinde çok önemlidir. Tüberküloz hastalığı da erken teşhis ve tedavi ile tamamen iyileşebilen bir hastalıktır. Akdeniz anemisi (talasemi), kalıtsal bir hastalık olup; anne ve/veya baba taşıyıcılığı önemlidir 6 . Talasemi majör ağır seyirli olup; Talasemi minör daha hafif seyirlidir. Anne ve babanın her ikisinde talasemi minör hastalığı olması durumunda çocukların \%25’inde talasemi majör görülür6,7. Türk Medeni Kanunu gereği evlenecek kişilerin "Sağlık Raporu" almaları zorunludur8. $\mathrm{Bu}$ raporlar düzenlenirken yapılan testler sayesinde evlenecek çiftlerin evlilik öncesinde sağlık taramaları yapılarak, mevcut bulaşıcı hastalıklar tespit edilmekte ya da gerekli bilgilendirme yapılmakta veya tedavi edilmektedir. Ayrıca ileride doğacak çocukların sağlı̆̆ı için birtakım önlemlerin alınması sağlanmaktadır. Evlilik raporu düzenlenmesi Aile Hekimliği Kanununda aile hekiminin görevleri içinde yer alan bir hizmettir. Çünkü Aile Hekimliği Kanununun 4. maddesinde "İlgili mevzuatta birinci basamak sağlık kuruluşları ve resmî tabiplerce kişiye yönelik düzenlenmesi öngörülen her türlü sağlı raporu, sevk evrakı, reçete ve sair belgeleri düzenlemek" ibaresiyle aile hekiminin görev ve sorumlulukları arasında yer almaktadir 9 .

Çalışmamızda, aile sağlığı merkezine; evlilik öncesi başvuran çiftlere yapılan sağlık değerlendirmeleri ve sonuçları incelenmiştir. Aile Hekimi tarafından düzenlenen evlilik raporlarının çiftler ve doğacak çocuklarının sağlığı açısından önemi konusunda farkındalık oluşturmak amaçlanmıştır.

\section{Gereç ve Yöntem}

Çalışmamızda 01.01.20 11 ile 30.12.2013 tarihleri arasında İstanbul'da bulunan bir aile sağlığı merkezine evlilik öncesi raporu almak için başvuran kişilerin Anti-HCV, AntiHBs, Anti-HIV, VDRL, HBsAg, hemogram, kan grubu tetkik sonuçları ile akciğer grafisi ile taraması yapılan tüberküloz hastalığına yönelik sonuçlar retrospektif olarak 
değerlendirilmiştir. Çalışmanın yapıldığı aile sağlığı merkezinin hizmet verdiği bölge sosyoekonomik olarak orta düzeydedir.

Akciğer grafileri taraması radyoloji ünitesinin düzenlediği rapora göre değerlendirilmiştir. Hemogram sonuçları değerlendirildiğinde ise hemoglobin $(\mathrm{Hb})$ değeri kadınlarda <12gr/dl, erkeklerde <13gr/dl anemi olarak kabul edilmiştir.

İstatistiksel Analiz: Verilerin değerlendirilmesinde ortalama, standart sapma, frekans istatistiksel yöntemleri kullanılmış olup SPSS15.o bilgisayar yazılımı ile yapılmıştır.

\section{Bulgular}

Aile sağlığı merkezine 01.01.2011-30.12.2013 yılları arasında evlilik öncesi rapor için

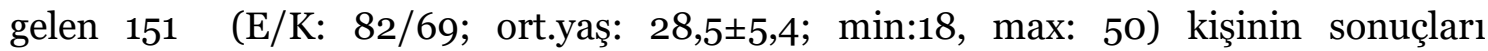
değerlendirilmiştir. Kadınların yaş ortalamaları 26,90 $\pm 6,42$ yıl iken, erkeklerin yaş ortalaması 29,355,47 yıldır. En sık evlilik başvurusu yaşı kadınlarda 22, erkeklerde 26 bulunmuştur. Her iki cinste toplamda en sık evlilik başvuru yaşının 24 olduğu sonucuna varılmıştır. Başvuru sonuçları değerlendirildiğinde; VDRL, Anti-HIV pozitifliğine ve akciğer grafisinde akut/kronik tüberküloz infeksiyonu bulgusuna rastlanmamıştır. Anti-HIV, HBsAg, Anti-HBs pozitifliği sırasıyla o(\% 0,0), 3(\% 1,9), $3(\%$ 1,9) kişide saptanmıştır. HBsAg pozitifliği saptanan 3 kişi erkek ve yaş ortalamaları

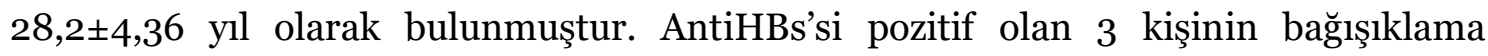
durumları sorgulanarak (E/K: 2/1; ort. yaş sırasıyla: 29,11 $\pm 6,42 / 26,02 \pm 6,27$ yll) oluşmuş olan bu bağışıklığın aşı yoluyla mı yoksa geçirilmiş enfeksiyon sonucunda mı kazandıkları sorulmuştur. Başvuranların 145’inde Anti-HBs negatiftir (E/K:77/68; ort.yaş sırasıyla: $29,18 \pm 6,48 / 26,39 \pm 5,80$ yıl). Bağışıklı̆̆ı olmayanlara Hepatit B hastalığı ile ilgili bilgilendirme ve danışmanlık verilmiştir. Çalışmada her başvuran kişiden hemogram istenmediği saptanmıştır. Dosyadan kaydedilen 60 hemogram tetkikinde, 7'si kadın $(\% 11,6)$ ve 4'ü erkek $(\% 6,7)$ olmak üzere toplam 11 kişide anemi olduğu saptanmıştır $(\% 18,3)$. Tüm başvurular incelendiğinde; en sık kan grubunun A (+) (\%43,o; $n=66)$, en nadir kan grubunun o kişi ile $\mathrm{AB}(-)$ olduğu (\%o,o). 69 kadından 7’inin $\mathrm{Rh}(-)$ kan grubuna sahip olduğu sonucuna varılmıştır (Tablo 1). Hemoglobin elektroforezi çalışmanın yapıldığı dönemin tamamında zorunlu olmamasına karşın 40 (E/K:26/14) kişinin hemoglobin elektroforezi yapılmış ve değerlendirildiğinde; 4’ü (E/K:3/1) ileri tetkik için hematolojiye yönlendirilmiştir. İncelenen dosyalarda kadınların 5 ’i gebe olduğu için akciğer grafisine yönlendirilmemiş sadece fizik 
muayeneleri yapılmıştır. Kendi kan grupları Rh(-) evlenecekleri kişinin $\mathrm{Rh}(+)$ olan dolayısıyla Rh uygunsuzluğu olarak tanımladığımız 5 kadına $\mathrm{Rh}$ uygunsuzluğu ile ilgili eğitim ve danışmanlık hizmeti verilmiştir. $\operatorname{HBsAg}(+)$ olan 3 kişinin evlenecekleri kişilerin hepatit markerleri istenerek değerlendirilmiş ve bu kişilere Hepatit B hastalı̆̆ hakkında bilgilendirilme yapılarak aktif bağışıklama programına alınmıştır.

Tablo 1: Kişilerin cinsiyetlerine göre kan grupları ve Rh faktörünün dağılımı

\begin{tabular}{|c|c|c|c|c|c|c|c|c|}
\hline & \multicolumn{4}{|l|}{ Rh(+) } & \multicolumn{4}{l|}{ Rh(-) } \\
\hline & O & A & B & AB & O & A & B & AB \\
\hline Kadin n (69) & 23 & 27 & 10 & 2 & 3 & 2 & 2 & O \\
\hline Erkek n (82) & 22 & 36 & 11 & 5 & 5 & 1 & 2 & O \\
\hline Toplam n (151) & 45 & 63 & 21 & 7 & 8 & 3 & 4 & 0 \\
\hline
\end{tabular}

\section{Tartışma}

Evlilik raporu için başvuran çiftlerden herhangi birinde HIV, HBsAg veya HCV pozitifliğinin bulunması evlenmeye yasal engel oluşturmamaktadır ${ }^{10}$. Bu durumda çiftlerden hasta olana bilgi verilmekte, ancak rızası dahilinde evleneceği kişiye bilgi verilebilmektedir. Hepatit B ve Hepatit C kronik karaciğer hastalıklarının en önemli nedenleri arasında olup; bildirimi zorunlu hastalıklardır ${ }^{4,11}$. Ülke genelini kapsayan toplum tabanlı bir viral hepatit prevalans çalışması olan ve Türk Karaciğer Araştırmaları Derneği (TKAD) tarafından 2008-2011 yılları arasında gerçekleştirilen çalışmada ki sonuçlar değerlendirildiğinde HBsAg pozitifliği \%4, anti-HBs pozitifliği ise \%32 olarak saptanmıştır4. HBsAg pozitifliğinin batı bölgelerinde daha düşük olduğu belirlenmiştir4,12 . Çalışmamızda HBsAg pozitifliği \%1,9 bulunmuştur. 2010 yılının Türk Karaciğer Araştırmaları Derneği Ulusal Hepatit Sıklığı Çalışmasında da (TÜRKHEP) olduğu gibi çalışmamızda da erkeklerdeki sıklığın daha fazla olduğu görülmüştür4. Yıldırım ve ark.'nın çalışmasında bu oran \%2,8; Özer ve ark.'nın çalışmasında \%4,2, Nohutçu'nun çalışmasında \%2,42, Yüksekkaya ve ark.'nın çalışmasında \%1,68 olarak bulunmuştur ${ }^{2,13-15}$. Çalışmamızda ki anti-HBs pozitifliği \%1,9 olarak bulunmuş olup hem Türkiye hem de Yıldırım ve ark.'nın (\%28), Yüksekkaya ve ark.'nın (\%14,72) çalışmasının oldukça altında bulunmuştur ${ }^{14,15}$. Dünyadaki HCV enfeksiyonu prevalansının \%2-2,3 olduğu tahmin edilmekte olup; Kuzey Avrupa'da prevalansın \%1' 
den düşük olduğu, Asya ve Afrika'da prevalansın en yüksek olduğu bilinmektedir ${ }^{4,16}$. Ülkemiz HCV enfeksiyonu prevalansının \%1-1,9 arasında değiştiği ülkeler arasında yer almaktadır ${ }^{17,18}$. Çalışmamızda Anti HCV pozitifliği 1 (\%o,64) olarak tespit edilmiştir. Özer ve ark.'nın çalışmasında anti HCV pozitifliği tespit edilmemiştir ${ }^{13}$. Yüksekkaya ve ark.'nın çalışmasında anti-HCV \%o,54 olarak bulunmuştur ${ }^{15}$. Çalışmamızda HBsAg ve anti HCV'si pozitif bulunan kişiler evlenecekleri kişi ile birlikte ileri tetkikleri için enfeksiyon hastalıkları polikliniğine yönlendirilerek tedavi ya da bağışıklamalarının yapılması sağlanmıştır. Yıldırım ve ark.'ının çalışmasında da aynı prosedürün uygulandığı görülmektedirr14. HIV çoğunlukla sağlıklı taşıyıcılarla bulaştırılmaktadır ${ }^{17}$. Sağlık Bakanlığı Bulaşıcı Hastalıklar Daire Başkanlığı istatistiksel verilerine göre ülkemizde, 1985 yılından 2016 yılı sonuna kadar doğrulaması yapılan 13.158 HIV(+) kişi ve 1537 AIDS vakası mevcuttur. Bildirimi yapılan vakaların \%84,8’i erkek, \%15,2'si ise kadındır. Yıllar itibarıyla hastalık trendinde artış gözlenmekte olup; 2011 yılında HIV(+) kişi sayısı 661 iken, 2016 yılında bu sayı dört katından daha fazla artış göstererek HIV(+) kişi sayısı 2470 olmuştur ${ }^{18}$. Yıldırım ve ark.'nın çalışmasında; antiHIV 2(\%o,7), Nohutçu'nun çalışmasında \%o,07 olarak bulunmuş; çalışmamızda ve benzer olarak Özer ve ark.'nın çalışmasında ise anti-HIV bütün hastalarda negatif olarak bulunmuştur ${ }^{2,13,14}$. Ülkemizde sfiliz prevalansı Batı ülkelerine yakın olup; Sağlık Bakanlığı Bulaşıcı Hastalıklar Daire Başkanlığı istatistiksel verilerine göre 2006 yılında vaka sayısı 507 morbidite hızı 0,73 (her 100.00o kişide), 2015 yılında vaka sayısı 502 morbidite hızı 0,65 (her 100.000 kişide) şeklindedir ${ }^{18}$. Nohutçu'nun çalışmasında VDRL(+)'liği \%o,12 olarak bulunmuş, Yıldırım ve ark. ile Özer ve ark.'nın çalışmalarında da çalışmamızdaki sonuca benzer olarak VDRL(+)'liği saptanmamıştır²,13,14. Evlilik raporları düzenlenirken istenilen tetkiklerden birisi de tam kan sayımıdır. Kalıtsal Hastalıklarla Mücadele Kanunu'na tüm kalıtsal kan hastalıklarının tespit edilmesi ve danışmanlık hizmeti verilmesi amaçlanmaktadır. Hemoglobinopatilerin özellikle endemik olduğu Akdeniz bölgesinde hemoglobin elektroforezi çok önemli olmasına karşın son dönemlerde Ankara ve İstanbul başta olmak üzere tüm ülkede yaygın olarak istenmektedir ${ }^{19}$. Çalışmanın yapıldığı dönemde hemoglobinopati taramasının zorunlu olmaması nedeniyle her hastanın hemogramı ve hemoglobin elektroforezinin istenmemiş olması ve istenilenlerin bir kısmının da sonuçlarının dosyalanmamış olması çalışmanın kısıtlılıklarından sayılabilir. Ulutaş ve ark.'nın Kadirli bölgesinde evlilik öncesi bireylerde yaptıkları hemoglobinopati 
taramasında beta-talesemi taşıyıcılığının Türkiye ortalamasının üzerinde olduğunu tespit etmişlerdir ${ }^{20}$.

Çalışmamızda evlilik raporu almak için başvuran kişilerden istenilen tetkiklerden biride kan grubu tetkikidir. Yapılan tetkikler sonucunda kadınların Rh (-) kan grubuna evlenecekleri erkeklerin $\mathrm{Rh}(+)$ kan grubuna sahip olmaları durumunda; ileride gelişebilecek gebelik durumlarında ortaya çıkabilecek $\mathrm{Rh}$ uygunsuzluğu ile ilgili olarak bilgilendirme yapılmış ve Rh izoimmünizasyonuna karşı annenin alması gereken önlemler anlatılmıştır. Çalışmamızda Rh negatifliği olan ve eşiyle uygunsuzluğu tespit edilen 5 kadına gebelikleri sırasında karşılaşılabileceği tıbbi sorunlar ve almaları gereken önlemler aile hekimi tarafından anlatılmıştır. Yıldırım ve ark.'nın çalışmasında da 148 kadından 18'inde Rh(-) kan grubu tespit edilmiş olup gerekli danışmanlığın verildiği belirtilmektedir ${ }^{14}$. Evlilik raporu düzenlenmesi sırasında gebeliği mevcut olan kadınlarda radyolojik tetkiklerin yapılamaması özel bir durumdur. Bu durumda evlilik raporunun aile hekiminde kalan nüshasına kişiye gebeliğinden dolayı radyolojik tetkikinin yapılamadığı belirtilmektedir. Birinci basamak sağlık kurumlarında evlilik raporu öncesi istenilen testler ücretsiz olarak yapılmaktadır.

\section{Sonuç}

Çalışmamızda tetkikleri yapılan bulaşıcı hastalıkların oranın düşük çıktığı düşünülse de; bu alanda daha geniş saha çalışmalarının yapılması ve bir veri havuzunun oluşması adı geçen hastalıkların yaygınlığı ve önlenmesi konusunda evlilik öncesi yapılan taramaların ve verilen danışmanlığın etkinliğini daha sağlıklı bir şekilde ortaya koyacaktır. Bu tetkikler dışında her çiftin yapılan fizik muayeneleri, bulaşıcı ve genetik geçişli hastalıklarla ilgili yapılan bilgilendirmeler ve çiftlere yapılan aile planlaması danışmanlığının her biri ayrı bir önem taşımaktadır.

Evlilik öncesi sağllk raporunun düzenlenmesi evlenecek çiftler açısından sadece bir prosedür ve zorunluluk olarak değerlendirilmeyip; günümüzde önemi ve sılklı̆̆ gittikçe artan bulaşıcı hastalıklar ile genetik geçişi olan hastalıklarla ilgili danışmanlık hizmeti verilmesi açısından fırsat olarak değerlendirilmelidir. Önemli bir halk sağlı̆̆ı sorunu olan cinsel yolla bulaşan hastalıkların önlenmesi ve genetik geçişli hastalıklarla ilgili yapılan tarama ve danışmanlıklarla da sağlıklı nesillerin oluşması konularında aile sağlığı merkezlerinde görev yapan aile hekimlerine büyük görevler düşmektedir. 


\section{Çalışmanın Kısıtlılıkları}

Çalışmada 2011-2013 yılları arasında Aile Sağlığı Merkezi’nde geriye dönük tüm evlilik raporları verileri incelenmiş olup; dolayısıyla sosyo-demografik verileri içeren ayrıntılı bir anket kullanılamamıştır. $\mathrm{Bu}$ nedenle tartışma kısmında bu verilerden yararlanılamamıştır. Ayrıca çalışmanın bir Aile Sağlığı Merkezi’nde yapılıyor olması da diğer kısıtllı̆ı̆ı olarak belirtilebilir.

\section{KAYNAKLAR}

1. Erdoğan AF. Erişkinde tarama testleri. http://www.ailehekimince.com/ taramatestleri.ppt. Erişim Tarihi 04 Nisan 2018.

2. Nohutçu NZ. Birinci basamakta önleme çalışmaları: Başarılarımız ve yetersizliklerimiz. Türk HIV (AIDS) Dergisi. 2006;9(3):173-178.

3. Evlilik öncesi danışmanlık rehberi. https://sbu.saglik.gov.tr/Ekutuphane/ kitaplar/Evlilikoncesi\%20DanismanlikRehberi.pdf Erişim Tarihi 04 Nisan 2018.

4. Türkiye Viral Hepatitler Tanı ve Tedavi Kılavuzu 2017. https://www.vhsd.org/tr/news/desc/5782/turkiye-viral-hepatitliler-tani-vetedavi-kilavuzu-2-7.html. Erişim tarihi o3 Ekim 2018.

5. T.C. Sağlık Bakanlığı Ana Çocuk Sağlı̆̆ı ve Aile Planlaması Genel Müdürlüğü. Cinsel yolla bulaşan enfeksiyonlar. https://sbu.saglik.gov.tr/Ekutuphane /kitaplar/açsap42.pdf Erişim Tarihi 04 Nisan 2018.

6. Akdeniz anemisi taşıyıcılığı ve hastalığı. http://www.thd.org.tr/THD Halk /?sayfa=akdeniz\%20anemisi. Erişim Tarihi 04 Nisan 2018.

7. Tunç B, Timur İH. Tarama programları ve yöntemleri. Talasemi ve Hemoglobinopatiler. http://www.talasemifederasyonu.org.tr/pdf/tani/cansin Tedavi-5.pdf. Erişim Tarihi 04 Nisan 2018.

8. 4721 sayll Türk Medeni Kanunu. Madde: 136 . http://www.resmigazete.gov.tr/ eskiler/2001/12/20011208.htm. Erişim tarihi: 04 Ekim 2018.

9. Aile Hekimliği Uygulama Yönetmeliği 25.01.2013/ 28539 Saylı Resmi Gazete. http://ailehekimligi.gov.tr/component/content/article/102-gorusler/2372-ailehekimlii-uygulama-yoenetmelii.html. Erişim Tarihi 04 Ekim 2018.

10. Yücel Ö. Evlilik öncesi muayene ve testlerin hukuksal niteliği. Adli Bilimler Dergisi. 2009;8(4):37-47. 
11. Voigt AR, Neto MS, Spada C, Treitinger A. Seroprevalence of hepatitis B and hepatitis $\mathrm{C}$ markers among children and adolescents in the south brazilian region metropolitan area of Florianópolis, Santa Catarina. Braz J InfectDis. 2010;14:6065. doi: 10.1016/S1413-8670(10)70012-X.

12. Tözün N, Özdoğan $\mathrm{O}$, Çakaloğlu $\mathrm{Y}$, et al. A nationwide prevalence study and risk factors for Hepatitis A, B, C and D infections in Turkey. The 61st Annual Meeting of the American Association for the Study of Liver Diseases: The Liver Meeting $₫$ 2010. Hepatology. 52;S1:697.

13. Özer TT, Yula E, Deveci Ö, Yanık K, Durmaz S, Tekin A. Evlilik öncesi yapılan tarama testi sonuçlarının değerlendirilmesi. Klinik ve Deneysel Araştırmalar Dergisi. 2011;2(3):292-294. doi: 10.5799/ahinjs.01.2011.03.0057.

14. Yıldırım EB, Mutlu HH, Sağlam ZA. Aile hekimliği polikliniğine evlilik raporu için başvuran bireylerin değerlendirilmesi. Konuralp Tip Dergisi. 2015;7(2):99-102.

15. Yüksekkaya Ş, Kalem F. Konya ilinde evlilik öncesi testler için sağlık kuruluşlarına başvuran bireylerde HbsAg, anti-HBs ve anti-HCV seroprevalansı. Eur J HealthSci. 2016;2(3):85-88. doi: 10.5505/eurjhs.2016.57966.

16. Barut HŞ, Günal O. Dünyada ve Ülkemizde Hepatit C epidemiyolojisi. Klimik Dergisi. 2009;22(2):38-43.

17. Işık Balcı Y, Polat Y, Övet G, Karabulut A, Göncü F, Yıldırım K. Denizli devlet hastanesi kan bankasına başvuran kan vericilerin HBsAg, Anti-HCV, Anti-HIV ve VDRL tarama sonuçlarının değerlendirilmesi. İnfeksiyon Dergisi. 2009;23(3):117-119.

18. Bulaşıcı Hastalıklar Daire Başkanlığı İstatistiksel Verileri. www.thsk.gov.tr/component/k2/353-istatistiksel-veriler/bulasici-hastalıklardaire-baskanliği. Erişim Tarihi o4 Nisan 2018.

19. Balseven A, Özdemir Ç, Bilge Y. Olgu sunumu: Talasemi taşıyıcılığının belirlenmesi sorunu. STED. 2002;11(10):378.

20. Ulutaş KT, Şahpaz F, Sarıcı İŞ, et al. Evlilik öncesi hemoglobinopati taraması: Kadirli, Türkiye beta-talasemi açısından riskli bir bölge mi? Türk Biyokimya Dergisi. 2014;39(3):357-361. doi: 10.5505/tjb.2014.90217. 